\title{
Antioxidant, antimicrobial and sensorial effects of Rosemary (Rosmarinus officinalis $L$.) and Sage (Salvia officinalis $L$.) on Sea bass (Dicentrarchus labrax L.) fillets
}

\section{Biberiye (Rosmarinus officinalis $L_{\text {. }}$ ) ve adaçayı (Salvia officinalis L.)'nın levrek (Dicentrarchus labrax L.) filetoları üzerindeki antioksidan, antimikrobiyal ve duyusal etkilleri}

\section{Can Altınelataman ${ }^{1 *}$ • Duygu Kışla ${ }^{2}$ • Berna Kılınç ${ }^{1}$ • Evren Burcu Şen Yılmaz ${ }^{1}$ • Aslı Cadun Yünlü1 • Tolga Dinçer ${ }^{1}$ • Ufuk Çelik1}

${ }^{1}$ Ege University, Faculty of Fisheries, Seafood Processing Department, 35100, Bornova, Izmir, Turkey ${ }^{2}$ Ege University, Engineering Faculty, Food Engineering Department, 35100, Bornova, Izmir, Turkey

${ }^{*}$ Corresponding Author: can.altinelataman@ege.edu.tr

\section{How to cite this paper:}

Atınelataman, C., Kışla, D., Kılınç, B., Şen-Yılmaz, E.B., Cadun-Yünlü, A., Dinçer, T., Çelik, U., 2015. Antioxidant, antimicrobial and sensorial effects of Rosemary (Rosmarinus officinalis L.) and Sage (Salvia officinalis L.) on Sea bass (Dicentrarchus labrax L.) fillets. Ege J Fish Aqua Sci 32(3): 121-126. doi: 10.12714/egejfas.2015.32.3.01

\begin{abstract}
Özet: Bu çalışmada, biberiye (Rosmarinus officinalis) ve adaçayı (Salvia officinalis) yapraklarının su buharı distilatları ve su fazı ekstraktlarının toplamının levrek filetoları üzerindeki etkileri incelenmiştir. Bu amaçla bu bitkilerden aynı miktarda kullanılarak etken çözelti elde edilmiş, oda sıcaklığına getirilerek deniz levreği (Dicentrarchus labrax) filetolarına uygulanmış ve örnekler buzdolabı şartlarında 13.gün süresince depolamaya alınmıştır. Etkileri incelemek amacıyla örneklerin pH, TVB-N(Toplam Uçucu Bazik Azot), TBA(Tiyobarbutiric asit), renk, tekstürel, mikrobiyolojik ve duyusal analizleri yapılmıştır. Yapılan analizler sonucunda adaçayı ekstraktının TVB-N ve TBA, biberiye ekstraktının ise renk, duyusal ve tekstürel açıdan daha etkili olduğu tespit edilmiştir. TVB-N açısından kontrol grubu 36.35 \pm 0.89 değeri ile tüketim limitini aşmış iken biberiye grubu tüketilebilirlik limitini 13. Depolama gününde aşmıştır. Mikrobiyolojik açıdan her iki bitki ekstraktının da etkili olduğu saptanmıştır. Özellikle kontrol grubu sonuçları 6. Gün sınır limite ulaşmış iken her iki uygulama sonucu 6. Depolama gününde limit altında olarak tespit edilmiştir. Denemenin hiçbir grubunda rancidite açısından bozulma gözlenmemiştir.
\end{abstract}

Anahtar kelimeler: Biberiye, adaçayı, deniz levreği, bazı kalite özellikleri

Abstract: In this study, effects of sum of vapor distillate and water phase extract of rosemary and sage leaves on sea bass fillets quality, were investigated. For this purpose, effective solution was obtained with same amounts of these plants, cooled down to room temperature, applied to fillets and samples were stored in refrigerated conditions during 13 days. In monitoring period, pH, TVB-N (Total Viable Base -Nitrogen), TBA(Tiobarbutiric acid ), color, textural, microbiological and sensorial analysis of samples were done. In rosemary group Control sample was reached the consumption limits with the value of $36.35 \pm 0.89$ (mg TVB-N $/ 100$ $\mathrm{g}$ ) in the 10th day of storage. But with the effect of rosemary extraction, rosemary group 3 more days to reach the spoilage limit. In results, sage was determined as more effective for TBA, TVB-N, rosemary for textural, sensorial and color analysis. For antimicrobial influence, both leaves have positive effectiveness. Especially control goups of both groups reached the spoilage limit in the 6th day of storage period where as the extraction groups were still under the consumptional limits. No spoilage were observed in rancidity values in both groups of the trial.

Keywords: Rosemary, sage, sea bass, some quality spesifications

\section{INTRODUCTION}

Rosemary and sage belong to Lamiaceae family, their fragnant leaves used in Mediterranean diet as dried and fresh where sage is also drinkable as tea. Rosemary extract has powerful antioxidant capacity to block oxidation of unsaturated fatty acids mostly due to rosmarinic acid. In historical timeline, civilizations around habitats of these effective plants, people used them in mixtures for healing wounds, drugs and food enrichment. These two plants were evaluated for their functional and health effects by researchers (Karpinska et al., 2001; Durling et al., 2007; Gutierrez et al., 2008; Süntar et al., 2011; Chan et al., 2012; Kontogianni et al., 2013; Laborda et al., 2013; Russo et al., 2013; Zhang et al., 2013; Kaliora et al., 
2014; Pérez-Sánchez et al., 2014; Martins et al., 2015; Piskernik et al., 2016). Their ability as protecting quality in fish was investigated by several researches (Abutbul et al. 2004; Ortiz et al., 2009; Tironi et al., 2010; Li et al, 2012a and 2012b; Hernández et al, 2014a and b; Khalafalla et al. 2015). The leaf extract of R. officinalis had a bacteriostatic effect on $\mathrm{S}$. iniae. There was chemotypic variability among accessions of $R$. officinalis. In in vitro assays, the ethylacetate extract of accession no. 1 showed the highest antibacterial activity at 37.5 $\mathrm{mm} / \mathrm{mg}$ dry weight (Abutbul et al., 2004). The application of rosemary extract as antioxidant was effective to reduce and delay the appearance of lipid oxidation as well as the loss of red color (Tironi et al, 2010). Ortiz et al (2009) have reported that their results have shown an enhancement of lipid oxidation stability when employing a diet including natural antioxidants by replacement of synthetic ones during the commercialisation of frozen coho salmon. Li et al. (2012b) have reported that their study showed that a dipping treatment with either $0.2 \%$ tea polyphenols or $0.2 \%$ rosemary extract could effectively retard microbial growth, delay chemical deterioration, maintain or improve sensory attributes and extend the shelf-life of crucian carp for 6-8 days during refrigerated storage. In this study, investigation on quality protecting effects of rosemary and sage extracts on sea bass flllets, was aimed.

\section{MATERIAL AND METHOD}

\section{Fish Material}

Sea bass (Dicentrarchus labrax L.) samples were obtained from a special fish farm which is located in CeşmeIzmir. 300-350 grams fish size group was selected for the study. Samples were transported in ice box immediately to laboratory of faculty. Cleaning, degutting and filleting with skin removing process were done with synchronized process for extract. Dried rosemary and sage leaves were supplied from Ege University-Faculty of Agriculture.

\section{Extraction and Application of Rosemary and Sage}

Both of $16 \mathrm{~g}$. dried leaves of Rosmarinus officinalis and Salvia officinalis were washed with tap water, distilled in $400 \mathrm{ml}$ bi-distilled water. Distillation was terminated at 15 th minute. Distilate and extract were integrated in $250 \mathrm{ml}$. flask as dipping solution and cooled down to the room temperature. Fish fillets were placed wide plastic boxes as six for each trial, covered by dipping solution, just stirred for 10 minutes in room temperature separately, then taken out and placed into closed plastic boxes and stored in refrigerator at $0,+4^{\circ} \mathrm{C}$.

\section{Chemical Quality Control Analysis}

For determining the chemical quality control, $\mathrm{pH}$ values were measured according to Lima dos Santos et al. (1981) using a digital $\mathrm{pH}$ meter (HANNA). Thiobarbituric acid (TBA, mg malonaldehyde $/ \mathrm{kg}$ ) values were determined by Tarladgis et al. (1960) and total volatile basic nitrogen (TVB-N, mg N/100 g) values were determined as described by Vyncke (1996).

\section{Texture Analysis and Color Measurements}

Color measurement (Schubring, 2002) and textural profile analyze (TPA) was also performed by using the method of Schubring (2003).

\section{Microbiological Analysis}

Total Aerobic Bacteria count was determined as log CFU/g by the method of Harrigan and McCance (1976)

\section{Sensorial Analysis}

Sensorial assessment trials were performed according to Williams and Arnold (1992) by 10 panelists for each sensorial panels.

\section{Statistical Analyses}

One-way analyses of variance (ANOVA) were carried out for difference in group. Independed T-Test was used for determining differences between groups. The software SPSS 9.05 was used.

\section{RESULTS AND DISCUSSION}

\section{Results of Rosemary Group}

\section{Chemical quality control analysis results of rosemary group}

For TBA, both group were under limits for consumers. At day of 7 , control group reached to $1.12 \mathrm{mg} \mathrm{MDA} / \mathrm{kg}$ where rosemary group has $0.59 \mathrm{mg}$ MDA (malonaldehyde)/ $\mathrm{kg}$. Khalafalla et al. (2015) have reported that TBA values were around $0.4 \mathrm{mg} \mathrm{MDA} / \mathrm{kg}$ at day 6 where the control group reached over $0.8 \mathrm{mg} \mathrm{MDA} / \mathrm{kg}$. Cadun et al. (2008) have reported that in day 75 , TBA values of marinated shrimp which treated by rosemary oil, was $2.4 \mathrm{mg} \mathrm{MDA} / \mathrm{kg}$ where the control was $6.6 \mathrm{mg} \mathrm{MDA} / \mathrm{kg}$. When the control group was reached the consumption limits (EC, 2008) of TVB-N on the day 10 with the value of $36.35 \pm 0.89 \mathrm{mg} / 100 \mathrm{~g}$, the rosemary group was still under the limits of consumers. The rosemary group was reached the consumer's limit (35 mg TVB-N/100g) on the day 13th.. Khalafalla et al. (2015) have reported that no any protecting impact of rosemary for TVB-N values on Nile tilapia where thyme has reducing ability. Cadun et al. (2008) have reported that in day 75 , TVB-N value of marinated shrimp with rosemary extract, was $5.6 \mathrm{mg} / 100 \mathrm{~g}$ where the control was 7.0 $\mathrm{mg} / 100 \mathrm{~g}$. $\mathrm{pH}$ values of rosemary group were determined higher than control in both analyze days. The last day of the storage the values of control and the rosemary group were $6.61 \pm 0.00$ and 6.72 \pm 0.01 , respectively $(P<0.05)$ (Table 1).

\section{Texture profile analysis results of rosemary group}

When we compare the textural attributes of control and rosemary groups just on the day 4th significant differences $(P<0.05)$ were determined between the attributes of hardness and springiness. It was determined that the values of the rosemary group were softer and less springiness (Table 2). 
Table 1. Chemical quality control analysis results of rosemary group

\begin{tabular}{|c|c|c|c|c|}
\hline Groups & Days & TBA (mg MDA/kg) & TVB-N (mg/100g) & $\mathrm{pH}$ \\
\hline \multirow{5}{*}{$\begin{array}{l}\overline{0} \\
\text { 혼 } \\
\text { 인 }\end{array}$} & 0 & $0.54 \pm 0.25^{1}$ & $20.69 \pm 1.02^{1}$ & $6.11 \pm 0.021$ \\
\hline & 4 & $0.94 \pm 0.05 \mathrm{a} 1$ & $21.28 \pm 0.89$ a 1 & $6.15 \pm 0.01$ a2 \\
\hline & 7 & $1.12 \pm 0.28 \mathrm{a} 2$ & $21.72 \pm 0.63 \mathrm{a} 1$ & $6.33 \pm 0.01$ a3 \\
\hline & 10 & $1.14 \pm 1.00 \mathrm{a} 2$ & $36.35 \pm 0.89$ a2 & $6.61 \pm 0.00$ a4 \\
\hline & 13 & - & & - \\
\hline \multirow{5}{*}{ 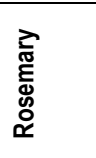 } & 0 & - & - & - \\
\hline & 4 & $0.23 \pm 0.04 b 1$ & $18.62 \pm 0.00^{b 1}$ & $6.23 \pm 0.00 \mathrm{~b} 1$ \\
\hline & 7 & $0.59 \pm 0.03 \mathrm{~b} 2$ & $19.80 \pm 1.02^{\mathrm{b} 1}$ & $6.40 \pm 0.01$ b2 \\
\hline & 10 & $1.37 \pm 0.54$ аз & $33.98 \pm 0.51$ b2 & $6.59 \pm 0.01$ b3 \\
\hline & 13 & $1.51 \pm 0.14^{4}$ & $48,47 \pm 1.35^{3}$ & $6.72 \pm 0.01^{4}$ \\
\hline
\end{tabular}

Arithmetic means and standard deviation ( \pm ), different superscripts numbers between rows characterize significant differences ( $p<0.05$ ) in side of the groups during storage period. Different superscript letters between the parallel analysis period characterize significant difference between control and extract groups on the same day. $n=3$ for each analysis.

Table 2. Texture profile analysis results of rosemary group.

\begin{tabular}{|c|c|c|c|c|c|c|c|}
\hline Groups & Days & Hardness(g) & Springiness & Chewiness & Cohesiveness & Resilience & Adhesiveness \\
\hline \multirow{5}{*}{ 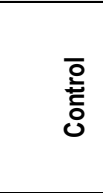 } & 0 & $1228.04 \pm 246.221$ & $0.25 \pm 0.05^{1}$ & $91.99 \pm 29.30^{1}$ & $0.24 \pm 0.071$ & $0.12 \pm 0.03^{1}$ & $-5.70 \pm 2.89^{1}$ \\
\hline & 4 & $1762.40 \pm 476.27^{\mathrm{a} 1}$ & $0.29 \pm 0.04 \mathrm{a} 1$ & $148.96 \pm 65.91^{\mathrm{a} 1}$ & $0.22 \pm 0.04 \mathrm{a} 1$ & $0.12 \pm 0.03^{a} 1$ & $-7.29 \pm 4.04 \mathrm{a} 1$ \\
\hline & 7 & $1795.53 \pm 621.34^{\mathrm{a} 1}$ & $0.28 \pm 0.04$ a1 & $131.97 \pm 54.76^{\mathrm{a} 1}$ & $0.21 \pm 0.066^{a 1}$ & $0.11 \pm 0.03^{\mathrm{a} 1}$ & $-19.99 \pm 4.93$ а2 \\
\hline & 10 & $1499.27 \pm 464.74^{\mathrm{a} 1}$ & $0.26 \pm 0.06^{\mathrm{a} 1}$ & $116.14 \pm 64.13^{a 1}$ & $0.22 \pm 0.066^{a 1}$ & $0.13 \pm 0.03^{\mathrm{a} 1}$ & $-20.35 \pm 2.48$ a2 \\
\hline & 13 & - & - & - & - & - & - \\
\hline \multirow{4}{*}{ 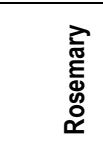 } & 0 & - & - & - & - & - & - \\
\hline & 4 & $1089.05 \pm 411.52^{\mathrm{b} 1}$ & $0.22 \pm 0.04$ b1 & $75.76 \pm 28.59 \mathrm{a} 1$ & $0.26 \pm 0.10^{a} 1$ & $0.14 \pm 0.07 \mathrm{a}^{\mathrm{1}}$ & $-4.00 \pm 2.80 \mathrm{a} 1$ \\
\hline & 7 & $1345.76 \pm 281.70^{a 1}$ & $0.29 \pm 0.11 \mathrm{a} 1$ & $93.40 \pm 44.77 \mathrm{a} 1$ & $0.19 \pm 0.03 \mathrm{a} 1$ & $0.10 \pm 0.02^{\mathrm{a} 1}$ & $-7.10 \pm 3.92^{\mathrm{a} 1}$ \\
\hline & 10 & $1445.04 \pm 682.48^{\mathrm{a} 1}$ & $0.24 \pm 0.05^{\mathrm{a} 1}$ & $110.61 \pm 63.87^{a 1}$ & $0.24 \pm 0.088^{a 1}$ & $0.12 \pm 0.05^{\mathrm{a} 1}$ & $-23.99 \pm 3.13$ a2 \\
\hline
\end{tabular}

Arithmetic means and standard deviation ( \pm ), different superscripts numbers between rows characterize significant differences ( $p<0.05)$ in side of the groups during storage period. Different superscript letters between the parallel analysis period characterize significant difference between control and extract groups on the same day. $n=10$ for each analysis.

\section{Color measurement values of rosemary group}

When we compare the color values, the $L^{*}$ values of the rosemary group were almost higher than the control in each analyze day. While $a^{*}$ and $b^{*}$ brought us higher values for this group. It can be said that rosemary group was lighter, less green and much yellow. Tironi et al. (2010) have reported similar results that rosemary extract has ability to slow down by reducing value $\mathrm{a}$, therefore loss of red color (Table 3 ).

Table 3. Color measurement values of rosemary group.

\begin{tabular}{|c|c|c|c|c|}
\hline Groups & Days & $\mathrm{L}^{*}$ & $a^{*}$ & $\mathbf{b}^{*}$ \\
\hline \multirow{5}{*}{$\begin{array}{l}\overline{\text { 은 }} \\
\text { 잉 }\end{array}$} & 0 & $54.79 \pm 1.58^{1}$ & $-1.30 \pm 0.271$ & $12.05 \pm 1.16^{1}$ \\
\hline & 4 & $52.12 \pm 1.96$ & $-1.17 \pm 0.15 \mathrm{a}^{1}$ & $11.30 \pm 0.86$ a 12 \\
\hline & 7 & $57.50 \pm 2.44$ a2 & $-0.97 \pm 0.92 \mathrm{a}^{\mathrm{a}}$ & $10.67 \pm 1.23$ a2 \\
\hline & 10 & $52.64 \pm 2.74$ a 1 & $-1.43 \pm 0.14 \mathrm{a} 1$ & $10.22 \pm 0.98$ a2 \\
\hline & 13 & - & - & - \\
\hline \multirow{5}{*}{ 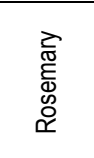 } & 0 & - & - & - \\
\hline & 4 & $57.08 \pm 3.54$ b12 & $-1.00 \pm 0.37$ a1 & $12.68 \pm 0.79 \mathrm{~b} 1$ \\
\hline & 7 & $60.23 \pm 2.42^{\mathrm{b} 1}$ & $-1.19 \pm 0.19 a_{1}$ & $11.34 \pm 3.74$ a1 \\
\hline & 10 & $56.36 \pm 2.45$ b2 & $-0.95 \pm 0.34 b 1$ & $14.25 \pm 0.73 \mathrm{~b} 1$ \\
\hline & 13 & $57.98 \pm 2.41^{12}$ & $-0.91 \pm 0.591$ & $13.53 \pm 1.671$ \\
\hline
\end{tabular}

Arithmetic means and standard deviation $( \pm)$, different superscripts numbers between rows characterize significant differences $(p<0.05)$ in side of the groups during storage period. Different superscript letters between the parallel analysis period characterize significant difference between control and extract groups on the same day. $n=10$ for each analysis.

\section{Microbiological quality control analysis results of rosemary group}

The initial total aerobic mesophilic bacteria (TAMB) counts of the raw material used was $4.96 \pm 0.05 \log \mathrm{CFU} / \mathrm{g}$ for rosemary trial. TAMB counts of the experimental groups showed $1 \mathrm{log}$ unit decrease as compared to control groups after 3 days of storage. Depending on the initial microbiological load of the raw material, microbiological shelf-life of the control samples varied. For rosemary trial, TAMB count of the control sample reached the maximum limit $7 \mathrm{log}$ cfu/g which is considered the maximum level for acceptability (Icmsf,1978) for marine fish, after 3 days of storage. However, rosemary group was still consumable at day 6. Khalfalla et al. (2015) have found lower Aerobic Plate Count in rosemary group of Nile tilapia than control group at day 9 where both groups exceeded the limit log 6 (Table 4).

Table 4. Microbiological quality control analysis results of rosemary group (log $\mathrm{CFU} / \mathrm{g}$ )

\begin{tabular}{llll}
\hline Group & 1.day & 3.day & 6.day \\
\hline Control & $5.52 \pm 0.04^{\mathrm{a}}$ & $6.51 \pm 0.13^{\mathrm{a}}$ & $7.97 \pm 0.02^{\mathrm{a}}$ \\
Rosemary & $5.19 \pm 0.05^{\mathrm{b}}$ & $5.41 \pm 0.02^{\mathrm{b}}$ & $6.05 \pm 0.02^{\mathrm{b}}$ \\
\hline
\end{tabular}

Arithmetic means and standard deviation ( \pm ), different superscripts numbers between columns characterize significant differences $(p<0.05)$ in side of the groups during storage period. $n=3$ for each analysis. 


\section{Sensorial analysis results of rosemary group}

According to the sensorial results odor, appearance, aroma and textural attributes were compared between control and rosemary groups. Rosemary group was still in good quality when the last day of the sensorial panel which was occurred on the day 7 th.

\section{Results of Sage Group \\ Chemical quality control analysis results of sage group}

Group sage has the lowest TBA values during storage when compared with the control group during storage. At the end of the storage group sage was found still in perfect quality while control group was found in good quality. At the end of storage group sage had lower TVB-N values than the control group (Table 5) $(P<0.05)$. No significant differences in both groups during storage period for $\mathrm{pH}$ values $(\mathrm{P}<0,05)$.

Table 5. Chemical quality control analysis results of sage group

\begin{tabular}{|c|c|c|c|c|}
\hline Groups & Days & TBA (mg malonaldehit/kg) & TVB-N (mg/100g) & $\mathrm{pH}$ \\
\hline \multirow{5}{*}{ 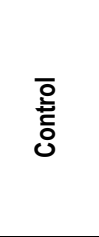 } & 0 & $0.80 \pm 0.221$ & $20.09 \pm 0.511$ & $6.26 \pm 0.011$ \\
\hline & 1 & $0.86 \pm 0.17 \mathrm{a} 1$ & $20.84 \pm 0.44$ a1 & $6.28 \pm 0.01$ a 1 \\
\hline & 4 & $2.11 \pm 0.34 \mathrm{a} 2$ & $18.92 \pm 1.02$ a 1 & $6.23 \pm 0.01 \mathrm{a} 1$ \\
\hline & 7 & $4.36 \pm 0.43$ а & $18.92 \pm 1.85$ a 1 & $6.34 \pm 0.02 \mathrm{a} 2$ \\
\hline & 10 & $4.20 \pm 0.08$ a 3 & $26.6 \pm 0.89 \mathrm{a} 2$ & $6.50 \pm 0.02^{\mathrm{a} 3}$ \\
\hline \multirow{5}{*}{ 急 } & 0 & - & - & - \\
\hline & 1 & $0.30 \pm 0.15^{\mathrm{b} 1}$ & $19.51 \pm 0.00 \mathrm{a} 1$ & $6.28 \pm 0.00 \mathrm{a} 1$ \\
\hline & 4 & $0.86 \pm 0.31 \mathrm{~b} 2$ & $17.73 \pm 1.54$ b2 & $6.22 \pm 0.02^{\mathrm{b} 2}$ \\
\hline & 7 & $1.30 \pm 0.07 \mathrm{~b} 2$ & $17.73 \pm 0.00 \mathrm{a} 2$ & $6.34 \pm 0.01$ b3 \\
\hline & 10 & $1.43 \pm 0.01 \mathrm{~b} 3$ & $21.72 \pm 0.63$ b3 & $6.51 \pm 0.01 \mathrm{b4}$ \\
\hline
\end{tabular}

Arithmetic means and standard deviation ( \pm ), different superscripts numbers between rows characterize significant differences $(p<0.05)$ in side of the groups during storage period. Different superscript letters between the parallel analysis period characterize significant difference between control and extract groups on the same day. $n=3$ for each analysis.

\section{Textural profile analysis results of sage group}

No significant differences were determined between sage and control group and no significant differences were determined during storage period (Table 6).

\section{Color measurement values of sage group}

$L^{*}$ values of control group were decreased during storage period; trends were not consistent when comparing. $a^{*}$ values of control group and group sage decreased during storage period. Trends were not consistent when groups were compared. $b^{*}$ values of both groups decreased at the end of the storage, trends were not consistent when comparing two groups (Table 7).
Table 7. Color measurments values of sage group

\begin{tabular}{|c|c|c|c|c|}
\hline Groups & Days & $L^{*}$ & $a^{*}$ & $b^{*}$ \\
\hline \multirow{4}{*}{ 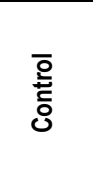 } & 1 & $60.82 \pm 1.56^{\mathrm{a} 1}$ & $-0.34 \pm 0.25^{a 1}$ & $15.91 \pm 0.78^{a 1}$ \\
\hline & 4 & $61.32 \pm 0.73$ a 1 & $-0.44 \pm 0.16$ a12 & $15.33 \pm 0.58 \mathrm{a} 12$ \\
\hline & 7 & $56.64 \pm 1.41$ a2 & $-0.71 \pm 0.33$ а 23 & $14.32 \pm 1.41 \mathrm{a} 2$ \\
\hline & 10 & $54.71 \pm 0.71$ аз & $-0.90 \pm 0.25$ аз & $14.62 \pm 0.70 \mathrm{a} 2$ \\
\hline \multirow{4}{*}{ 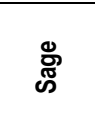 } & 1 & & & 15.8 \\
\hline & . & $53.81 \pm 1.01$ b2 & $-0.71 \pm 0.23$ & $14.11 \pm 1.41 \mathrm{a} 2$ \\
\hline & 7 & $57.30 \pm 0.85$ аз & $-0.57 \pm 0.24 b 12$ & $14.87 \pm 0.70 \mathrm{a} 12$ \\
\hline & 10 & $59.83 \pm 1.45$ a 1 & $-0.64 \pm 0.23 b 12$ & $15.23 \pm 0.51 \mathrm{~b} 12$ \\
\hline
\end{tabular}

Arithmetic means and standard deviation ( \pm ), different superscripts numbers between rows characterize significant differences $(p<0.05)$ in side of the groups during storage period. Different superscript letters between the parallel analysis period characterize significant difference between control and extract groups on the same day. $\mathrm{n}=10$ for each analysis.

Table 6. Textural profile analysis results of sage group

\begin{tabular}{|c|c|c|c|c|c|c|c|}
\hline Groups & $\begin{array}{c}\text { Storage } \\
\text { (days) }\end{array}$ & Hardness(N) & Adhesiveness & Springiness & Cohesiveness & Chewiness & Resilience \\
\hline \multirow{4}{*}{$\begin{array}{l}\text { 은 } \\
\text { 잉 }\end{array}$} & 1 & $16.35 \pm 4.28^{\mathrm{a} 1}$ & $-0.10 \pm 0.06$ a1 & $0.26 \pm 0.03^{a 1}$ & $0.23 \pm 0.06 \mathrm{a}^{\mathrm{a} 1}$ & $1.01 \pm 0.49 \mathrm{a} 1$ & $0.11 \pm 0.04^{\mathrm{a} 1}$ \\
\hline & 4 & $11.56 \pm 6.02^{\mathrm{a} 1}$ & $-0.05 \pm 0.05$ a1 & $0.26 \pm 0.05^{\mathrm{a} 1}$ & $0.26 \pm 0.13 \mathrm{a}_{1}$ & $0.71 \pm 0.45^{\mathrm{a} 1}$ & $0.12 \pm 0.06^{\mathrm{a} 1}$ \\
\hline & 7 & $15.60 \pm 6.01^{\mathrm{a} 1}$ & $-0.06 \pm 0.04$ a1 & $0.28 \pm 0.07^{\mathrm{a} 1}$ & $0.26 \pm 0.13 \mathrm{a} 1$ & $1.03 \pm 0.50^{\mathrm{a} 1}$ & $0.13 \pm 0.07^{a 1}$ \\
\hline & 10 & $14.38 \pm 3.77^{\mathrm{a} 1}$ & $-0.11 \pm 0.05$ a1 & $0.30 \pm 0.06^{\mathrm{a} 1}$ & $0.21 \pm 0.03$ a 1 & $0.89 \pm 0.32^{\mathrm{a} 1}$ & $0.10 \pm 0.02^{\mathrm{a} 1}$ \\
\hline \multirow{4}{*}{ 胥 } & 1 & $14.88 \pm 4.14 \mathrm{a} 1$ & $-0.08 \pm 0.06$ a1 & $0.23 \pm 0.04 \mathrm{a} 1$ & $0.21 \pm 0.05 \mathrm{a} 1$ & $0.75 \pm 0.36{ }^{a 1}$ & $0.11 \pm 0.03^{\mathrm{a} 1}$ \\
\hline & 4 & $11.74 \pm 4.64 \mathrm{a} 1$ & $-0.05 \pm 0.04 \mathrm{a} 1$ & $0.23 \pm 0.05^{a 1}$ & $0.26 \pm 0.11 \mathrm{a} 1$ & $0.70 \pm 0.38 \mathrm{a}^{\mathrm{a}}$ & $0.12 \pm 0.06^{\mathrm{a} 1}$ \\
\hline & 7 & $15.63 \pm 3.75^{a 1}$ & $-0.09 \pm 0.03 \mathrm{a}^{1}$ & $0.27 \pm 0.05^{a 1}$ & $0.22 \pm 0.11 \mathrm{a} 1$ & $0.91 \pm 0.40^{\mathrm{a} 1}$ & $0.11 \pm 0.06^{\mathrm{a} 1}$ \\
\hline & 10 & $14.73 \pm 5.10^{a} 1$ & $-0.09 \pm 0.05 a 1$ & $0.28 \pm 0.06^{\mathrm{a} 1}$ & $0.23 \pm 0.06 \mathrm{a}^{\mathrm{a} 1}$ & $0.99 \pm 0.59 \mathrm{a} 1$ & $0.12 \pm 0.04^{\mathrm{a} 1}$ \\
\hline
\end{tabular}

Arithmetic means and standard deviation ( \pm ), different superscripts numbers between rows characterize significant differences $(p<0.05)$ in side of the groups during storage period. Different superscript letters between the parallel analysis period characterize significant difference between control and extract groups on the same day. $n=3$ for each analysis. 


\section{Microbiological quality control analysis results of sage group}

The initial total aerobic mesophilic bacteria (TAMB) counts of the raw material used were $2.96 \pm 0.05 \mathrm{log}$ CFU/g for sage trial. TAMB counts of the experimental group showed 1 log unit decrease as compared to control groups after 3 days of storage. Depending on the initial microbiological load of the raw material, microbiological shelf-life of the control samples varied. TAMB count of the control sample (sage) almost reached the maximum limit of the microbiological criterion for fresh marine fish at day 6. However, experimental group (sage) was still consumable at day 6 (Table 8).

Table 8. Microbiological quality control analysis results of sage group (log $\mathrm{CFU} / \mathrm{g})$

\begin{tabular}{llll}
\hline Group & 1.day & 3.day & 6.day \\
\hline Control & $3.24 \pm 0.05^{\mathrm{a}}$ & $4.17 \pm 0.03^{\mathrm{a}}$ & $6.82 \pm 0.21^{\mathrm{a}}$ \\
Sage & $3.65 \pm 0.08^{\mathrm{b}}$ & $3.65 \pm 0.05^{\mathrm{b}}$ & $5.44 \pm 0.02^{\mathrm{b}}$ \\
\hline
\end{tabular}

Arithmetic means and standard deviation ( \pm ), different superscripts numbers between columns characterize significant differences $(p<0.05)$ in side of the groups during storage period. $n=3$ for each analysis.

\section{REFERENCES}

Abutbul, S., Golan-Goldhirsh, A., Barazani, O., Zilberg, D., 2004. Use of Rosmarinus officinalis as a treatment against Streptococcus iniae in tilapia (Oreochromis sp.). Aquaculture, 238:97-105. doi:10.1016/j.aquaculture.2004.05.016

Cadun, A., Kışla, D., Çaklı. 2008. Marination of deep-water pink shrimp with rosemary extract and the determination of its shelf-life. Food Chemistry, 109:81-87. doi:10.1016/j.foodchem.2007.12.021

Chan , E.W.C., Kong, L.Q., Yee, K.Y., Chua, W.Y., Loo, T.Y., 2012. Antioxidant and antibacterial properties of some fresh and dried Labiatae herbs. Free Radicals and Antioxidants, 2(3):20-27. doi:10.5530/ax.2012.3.3

Durling, N.E., Catchpole, O.J., Grey, J.B., Webby, R.F., Mitchell, K.A., Foo, L.Y., Perry, N.B., 2007. Extraction of phenolics and essential oil from dried sage (Salvia officinalis) using ethanol-water mixtures. Food Chemistry, 101:1417-1424. doi:10.1016/j.foodchem.2006.03.050

EC, Commission Regulation., 2008. Amending Regulation (EC) No 2074/2005 as regards the total volatile basic nitrogen (TVB-N) limits. (EC) No 1022/2008.

Gutierrez, J., Barry-Ryan, C., Bourke, P., 2008. The antimicrobial efficacy of plant essential oil combinations and interactions with food ingredients. International Journal of Food Microbiology, 124:91-97. doi:10.1016/j.ijfoodmicro.2008.02.028

Harrigan, W.F., McCance, M.E., 1976. Laboratory Methods in Food and Dairy Microbiology. London: Academic Press Inc.

Hernández, A., García García, B., Jordán, M.J., Hernández, M.D., 2014a. Improved conservation of gilthead seabream (Sparus aurata) in ice storage. The influence of doses of rosemary extract added to feed. Aquaculture, 426-427:31-40. doi: 10.1016/j.aquaculture.2014.01.018

Hernández, A., García García, B., Jordán, M.J., Hernández, M.D., 2014b. Natural antioxidants in extruded fish feed: Protection atdifferent storage temperatures. Animal Feed Science and Technology, 195:112-119. doi: 10.1016/j.anifeedsci.2014.06.003

Icmsf , 1978 .Microorganisms in foods, vol. 2. The International Commission on Microbiological Specifications for Foods, Toronto, Canada

\section{Results of sensorial analysis of sage group}

According to the sensorial results odor, appearance, aroma and textural attributes were compared between control and sage groups. Sage group was still in good quality in attributes of odor and aroma when the appearance and texture were in low quality limits in the last day of the sensorial panel which was occurred on the day 4th.

\section{CONCLUSION}

Using herbal extracts for different purposes in food industry is gaining importance in last decade included seafood sector. In present study it's showed that by dipping fillets in to solution obtained with equal amounts of dried leaves, sage was more effective for TBA, TVB-N, rosemary for textural, sensorial and color analysis, for antimicrobial influence, both leaves have almost same effectiveness versus control groups. These have clearly indicated that, sage was determined as more effective for chemical and rosemary was for other criterias. These herbs should be taken into more detailed further studies for not just protective effects for final products, but also as quality improving and human health factors.

Kaliora, A.C., Kogiannou, D.A.A., Kefalas, P., Papassideri, I.S., Kalogeropoulos, N., 2014. Phenolic profiles and antioxidant and anticarcinogenic activities of Greek herbal infusions; balancing delight and chemoprevention? Food Chemistry, 142:233-241. doi: 10.1016/j.foodchem.2013.07.056

Karpinska, M., Borowski, J., Danowska-Oziewicz, M., 2001. The use of natura antioxidants in ready-to-serve food. Food Chemistry, 72:5-9.

Khalafalla, F.A., Ali, F.H.M., Hassan, A-R.H.A., 2015. Quality improvement and shelf-life extension of refrigerated Nile tilapia (Oreochromis niloticus) fillets using natural herbs. Beni Suef University Journal of Basic and Applied Sciences, 4:33-40. doi: 10.1016/j.bjbas.2015.02.005

Kontogianni, V.G., Tomic, G., Nikolic, I., Nerantzaki, A.A., Sayyad, N., StosicGrujicic, S., Stojanovic, I., Gerothanassis, I.P., Tzakos, A.G., 2013. Phytochemical profile of Rosmarinus officinalis and Salvia officinalis extracts and correlation to their antioxidant and anti-proliferative activity. Food Chemistry, 136:120-129. doi:10.1016/j.foodchem.2012.07.091

Laborda, R., Manzano, I., Gamon, M., Gavidia, I., Boluda, R., 2013. Effects of Rosmarinus officinalis and Salvia officinalis essential oils on Tetranychus urticae Koch (Acari: Tetranychidae). Industrial Crops and Products, 48:106-110. doi:10.1016/j.indcrop.2013.04.011

Li, T., Hu, W., Li, J., Zhang, X., Zhu, J., Li, X., 2012a. Coating effects of tea polyphenol and rosemary extract combined with chitosan on the storage quality of large yellow croaker (Pseudosciaena crocea). Food Control, 25:101-106. doi:10.1016/j.foodcont.2011.10.029

Li, T., Li, J., Hu, W., Zhang, X., Li, X., Zhao, J., 2012b. Shelf-life extension of crucian carp (Carassius auratus) using natural preservatives during chilled storage. Food Chemistry, 135:140-145. doi: 10.1016/j.foodchem.2012.04.115

Lima dos Santos, C. A. M., James, D., Teutscher, F., 1981. Guidelines for chilled fish storage Experiment. FAO Fisheries Technical Paper, 210:1722.

Martins, N., Barros, L., Santos-Buelga, C., Henriques, M., Silva, S., Ferreira, I.C.F.R., 2015. Evaluation of bioactive properties and phenolic compounds in different extracts prepared from Salvia officinalis $L$. Food Chemistry,170:378-385. doi: 10.1016/j.foodchem.2014.08.096 
Ortiz, J., Larraín, M.A., Vivanco, J.P., Aubourg, S.P., 2009. Rancidity development during the frozen storage of farmed coho salmon (Oncorhynchus kisutch): Effect of antioxidant composition supplied in the diet. Food Chemistry, 115:143-148. doi:10.1016/j.foodchem.2008.11.076

Pérez-Sánchez, A., Barrajón-Catalán, E., Caturla, N., Castillo, J., BenaventeGarcía, O., Alcaraz, M., Micol, V., 2014. Protective effects of citrus and rosemary extracts on UV-induced damagein skin cell model and human volunteers. Journal of Photochemistry and Photobiology B: Biology 136:12-18. doi: 10.1016/j.jphotobiol.2014.04.007

Piskernik, S., Klančnik, A., Demšar, L., Možina, S.S., Jeršek, B., 2016. Control of Alicyclobacillus spp. vegetative cells and spores in apple juice with rosemary extracts. Food Control, 60:205-214. doi: 10.1016/j.foodcont.2015.07.018

Russo, A., Formisano, C., Rigano, D., Senatore, F., Delfine, S., Cardile, V. Rosselli, S., Bruno, M., 2013. Chemical composition and anticance activity of essential oils of Mediterranean sage (Salvia officinalis L.) grown in different environmental conditions. Food and Chemical Toxicology, 55:42-47. doi: 10.1016/j.fct.2012.12.036

Schubring, R., 2002. Texture measurement on gutted cod during storage in ice using a hand-held instrument. Inf. Fischwirtsch. Fischereiforsch, 49:2527.

Schubring,R.,2003. Colour measurement for the determination of the freshness of fish. In: J.B. Luten, J.Oehlenschlager and G. Olafsdottir (Ed.)Quality of fish from catch to consumer:Labelling, monitoring and traceability, Wageningen Academic Publishers, The Netherlands. pp. 251-263.
Süntar, I.., Küpeli Akkol, E., Keleş, H., Öktem, A., Başer, K.H.C., Yeşilada, E., 2011. A novel wound healing ointment: A formulation of Hypericum perforatum oil and sage and oregano essential oils based on traditional Turkish knowledge. Journal of Ethnopharmacology, 134:89-96. doi:10.1016/j.jep.2010.11.061

Tarladgis, B. G., Watts, B. M., Younathan, M. S., Dugan, L. Jr., 1960. A Distillation method for the quantitative determination of malonaldehyde in rancid foods. J. American Oil Chem. Soc., 37:44-48.

Tironi, V.A., Tomàs, M.C., Aǹon, M., 2010. Quality loss during the frozen storage of sea salmon (Pseudopercis semifasciata). Effect of rosemary (Rosmarinus officinalis L.) extract. LWT - Food Science and Technology, 43:263-272. doi:10.1016/j.lwt.2009.07.007

Vyncke, W., 1996. Comparison of the official EC method for the determination of total volatile bases in fish with routine methods. Archiv für Lebensmittelhygiene, 47:110 -112.

Williams, A.A., Arnold, G.M. 1992. The influence of presentation factors on the sensory assessment of beverages. Food Quality and Preferenceand preference, 3:101-107.

Zhang, L., Lin, Y.H., Leng, X.J., Huang, M., Zhou, G.H., 2013. Effect of sage (Salvia officinalis) on the oxidative stability of Chinese-style sausage during refrigerated storage. Meat Science, 95:145-150. doi: 10.1016/j.meatsci.2013.05.005 